University of Nebraska - Lincoln

DigitalCommons@University of Nebraska - Lincoln

Publications, Agencies and Staff of the U.S.

Department of Commerce

U.S. Department of Commerce

2011

\title{
Use of Fatty Acid Analysis to Determine Dispersal of Caspian Terns in the Columbia River Basin, U.S.A.
}

\author{
Christina J. Maranto \\ University of Washington - Seattle Campus, cmaranto@uw.edu \\ Julia K. Parrish \\ University of Washington - Seattle Campus \\ David P. Herman \\ NOAA Fisheries/National Marine Fisheries Service \\ André E. Punt \\ University of Washington - Seattle Campus \\ Julian D. Olden \\ University of Washington - Seattle Campus \\ See next page for additional authors
}

Follow this and additional works at: https://digitalcommons.unl.edu/usdeptcommercepub

Part of the Environmental Sciences Commons

Maranto, Christina J.; Parrish, Julia K.; Herman, David P.; Punt, André E.; Olden, Julian D.; Brett, Michael T.; and Roby, Daniel D., "Use of Fatty Acid Analysis to Determine Dispersal of Caspian Terns in the Columbia River Basin, U.S.A." (2011). Publications, Agencies and Staff of the U.S. Department of Commerce. 289. https://digitalcommons.unl.edu/usdeptcommercepub/289

This Article is brought to you for free and open access by the U.S. Department of Commerce at DigitalCommons@University of Nebraska - Lincoln. It has been accepted for inclusion in Publications, Agencies and Staff of the U.S. Department of Commerce by an authorized administrator of DigitalCommons@University of Nebraska - Lincoln. 


\section{Authors}

Christina J. Maranto, Julia K. Parrish, David P. Herman, André E. Punt, Julian D. Olden, Michael T. Brett, and Daniel D. Roby 


\title{
Use of Fatty Acid Analysis to Determine Dispersal of Caspian Terns in the Columbia River Basin, U.S.A.
}

\author{
CHRISTINA J. MARANTO,${ }^{*} \dagger \dagger$ JULIA K. PARRISH,${ }^{*} \dagger$ DAVID P. HERMAN,$\ddagger$ ANDRÉ E. PUNT $\dagger$ \\ JULIAN D. OLDEN, $\uparrow$ MICHAEL T. BRETT, $\S$ AND DANIEL D. ROBY** \\ ${ }^{*}$ University of Washington, Department of Biology, Seattle, WA 98195, U.S.A. \\ †University of Washington, School of Aquatic and Fishery Sciences, Seattle, WA 98195, U.S.A. \\ $\ddagger$ Environmental Conservation, NOAA Fisheries/National Marine Fisheries Service, Northwest Fisheries Science Center, 2725 \\ Montlake Boulevard, East, Seattle, WA 98112, U.S.A. \\ $\S$ University of Washington, Department of Civil and Environmental Engineering, Seattle, WA 98195, U.S.A. \\ ${ }^{* *}$ U.S. Geological Survey-Oregon Cooperative Fish and Wildlife Research Unit, Department of Fisheries and Wildlife, Oregon State \\ University, 104 Nash Hall, Corvallis, OR 97331, U.S.A.
}

\begin{abstract}
Lethal control, which has been used to reduce local abundances of animals in conflict with bumans or with endangered species, may not achieve management goals if animal movement is not considered. In populations with emigration and immigration, lethal control may induce compensatory immigration, if the source of attraction remains unchanged. Witbin the Columbia River Basin (Washington, U.S.A.), avian predators forage at dams because dams tend to reduce rates of emigration of juvenile salmonids (Oncorhynchus spp.), artificially concentrating these prey. We used differences in fatty acid profiles between Caspian Terns (Hydroprogne caspia) at coastal and inland breeding colonies and terns culled by a lethal control program at a mid-Columbia River dam to infer dispersal patterns. We modeled the rate of loss of fatty acid biomarkers, which are fatty acids that can be traced to a single prey species or groups of species, to infer whether and when terns foraging at dams had emigrated from the coast. Nonmetric multidimensional scaling showed that coastal terns had high levels of $C_{20}$ and $C_{22}$ monounsaturated fatty acids, whereas fatty acids of inland breeders were high in C18:3n3, C20:4n6, and C22:5n3. Models of the rate of loss of fatty acid showed that approximately $60 \%$ of the terns collected at Rock Island Dam were unlikely to bave bred successfully at local (inland) sites, suggesting that terns foraging at dams come from an extensive area. Fatty acid biomarkers may provide accurate information about patterns of dispersal in animal populations and may be extremely valuable in cases where populations differ demonstrably in prey base.
\end{abstract}

Keywords: Avian predator, dispersal, fatty acid, Hydroprogne caspia, salmon

Utilización de Análisis de Ácidos Grasos para Determinar la Dispersión de Hydroprogne caspia en la Cuenca del Río Columbia, E. U. A.

Resumen: Es posible que el control letal, que ha sido utilizado para disminuir las abundancias locales de animales en conflicto con humanos o con especies en peligro, no alcance las metas de manejo si no se considera el movimiento de los animales. En poblaciones, con emigración e inmigración, el control letal puede inducir la inmigración compensatoria, si la fuente de atracción permanece sin cambios. En la Cuenca del Río Columbia (Washington, E. U. A.), las aves depredadoras forrajean en las presas porque estas tienden a reducir las tasas de emigración de salmónidos juveniles (Oncorhynchus spp.), al concentrarlos artificialmente. Utilizamos diferencias en los perfiles de ácidos grasos entre (Hydroprogne caspia) en colonias de anidación ubicadas en la costa y tierra adentro y en aves sacrificadas por un programa de control letal para inferir sus patrones 
de dispersión. Modelamos la tasa de pérdida de biomarcadores de ácidos grasos, que son ácidos grasos que pueden ser rastreados hasta una especie o un grupo de especies presa, para inferir si y cuando emigraron de la costa las aves que forrajean en las presas. El escalamiento multidimensional no métrico mostró que los charranes costeros tenían niveles altos de ácidos grasos monoinsaturados $C_{20}$ y $C_{22}$, mientras que los ácidos grasos de los reproductores de tierra adentro tuvieron niveles altos de in C18:3n3, C20:4n6 y C22:5n3. Los modelos de la tasa de pérdida de ácido graso mostró que era poco probable que aproximadamente $60 \%$ de las aves recolectadas en la Presa Rock Island se bubieran reproducido en sitios (tierra adentro) locales, lo cual sugiere que los charranes que forrajean en presas provienen de un área extensa. Los marcadores de ácidos grasos pueden proporcionar información precisa sobre los patrones de dispersión en poblaciones animales y pueden ser extremadamente valiosos en casos en que las poblaciones difieren demostrablemente en la base de presas.

Palabras Clave: ácido graso, ave depredadora, dispersión, Hydroprogne caspia, salmón

\section{Introduction}

Understanding dispersal patterns of native animals is important given current threats (e.g., unsustainable levels of harvest, non-native species, climate change) to their populations (Hanski \& Simberloff 1997). By definition, source populations have a positive population growth rate, producing individuals that disperse, sometimes widely, including into areas where local mortality as a consequence of culling may affect regional population dynamics (Novaro et al. 2005). For example, Robinson et al. (2008) suggest that hunting cougars (Felis concolor) to reduce local abundance may induce compensatory immigration while simultaneously shifting regional population structure toward younger animals. Lethal control, which has been used to decrease local abundance of animals in conflict with humans or endangered species (Goodrich \& Buskirk 1995), may have unintended consequences, especially if the local source of attraction for dispersing individuals remains unchanged.

The Caspian Tern (Hydroprogne caspia) is a widespread, piscivorous seabird typically present in low abundances throughout its worldwide range (Wires \& Cuthbert 2000). In the Columbia River Basin (Washington, U.S.A.), the number of nesting Caspian Terns increased from a few pairs in 1984 to over 10,000 pairs in 2010 (Bird Research Northwest 2008), making this population of Caspian Terns the world's largest. Three factors contributed to this increase in abundance: loss of colony sites elsewhere in the region, dredge-spoil dumping in the lower river that created nesting habitat, and high food availability due to the annual release of approximately 200 million juvenile salmonids (Oncorbynchus spp.) from hatcheries throughout the Columbia River Basin (Wires \& Cuthbert 2000). At present, Caspian Terns in the Columbia River Basin are scattered among 6 breeding colonies (Bird Research Northwest 2008) (Fig. 1). In addition, terns are regular visitors to sites along the river that concentrate juvenile salmonids, including hatcheries and dams (Wiese et al. 2008). Minimizing the effects of predation on juvenile salmonids by avian predators at these facilities, by mechanisms including lethal con- trol, has been a management priority because the limits on dam- and reach-level mortality rates of endangered salmonids are strict (National Marine Fisheries Service 2002).

Because terns prey on juvenile salmonids (Wiese et al. 2008) and many salmonid populations are listed as endangered (McClure et al. 2003), tern diet has been intensively studied throughout the basin through analysis of gut contents and behavioral observations of prey delivered to chicks (Roby et al. 2003; Maranto et al. 2010). Gut contents may be readily identified but provide information on only the most recent meal and may be biased due to differential digestion of prey (Barrett et al. 2007). Observing prey deliveries to chicks may not yield information on adult diet because adults may not eat the same foods they feed their chicks (Hobson et al. 2002).

Fatty acid (FA) analysis has been used as an alternative method to analyses of gut contents and behavioral observations. Fatty acids comprise the majority of lipids found in the tissues of organisms and most commonly consist of long carbon chains (14-24 carbon molecules) with 0-6 double bonds terminating in methyl $\left(\mathrm{CH}_{3}\right)$ and carboxyl (COOH) groups (Budge et al. 2006). Because marine vertebrates have a limited capacity for de novo FA synthesis, select dietary FAs may be assimilated within their tissues with minimal modification (Iverson et al. 2004; Williams \& Buck 2010). For instance, Käkelä et al. (2009) found several FAs, including C14:0, C18:3n3, C18:4n3, and the $\mathrm{C}_{20}-\mathrm{C}_{22}$ monounsaturated fatty acids, are well correlated with diet. Despite modifications of FAs between consumption of prey and assimilation into tissue (Williams \& Buck 2010), diet can strongly influence the relative concentrations of specific FAs in predator tissue (Williams et al. 2009), which allows examination of the spatial, temporal, or demographic variation in diet among individuals, populations, or species (Thiemann et al. 2008).

Fatty acid biomarkers, or specific FAs that originate from a given species or groups of species (Budge et al. 2006), can be used to resolve prey-base differences. Certain FAs can be directly linked to taxonomic assemblages of primary producers (Dalsgaard et al. 2003), whereas others may be indicative of primary consumers, 


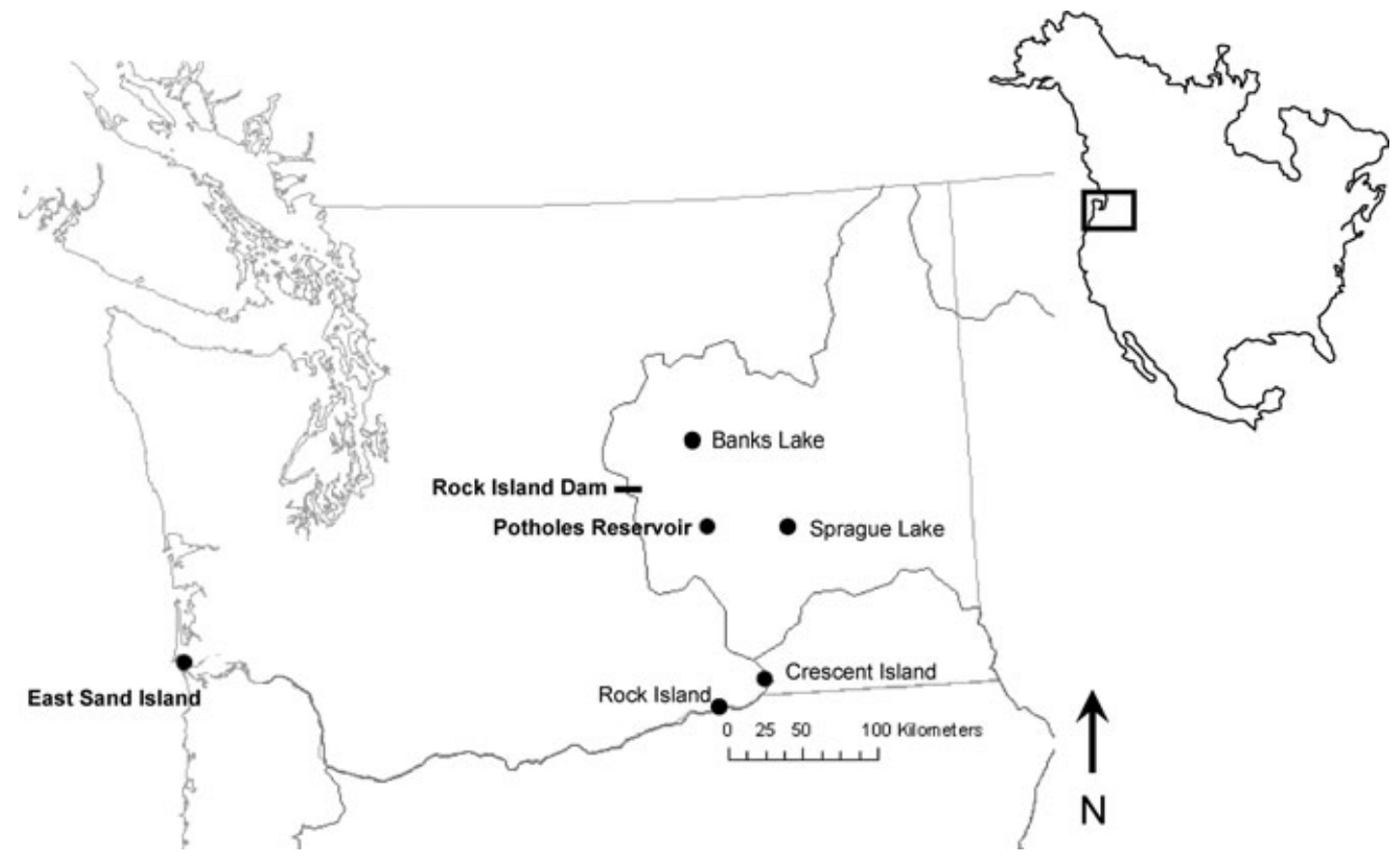

Figure 1. Location of Caspian Tern breeding colonies (dots) and Rock Island Dam (bar) in the Columbia River Basin. Terns were collected at East Sand Island (river km 8, 46 $15^{\prime} 45^{\prime \prime} \mathrm{N}, 123^{\circ} 58^{\prime} 06^{\prime \prime} \mathrm{W}$ ), Rock Island Dam (river $\mathrm{km} 730,47^{\circ} 20^{\prime} 35^{\prime \prime} \mathrm{N}, 120^{\circ} 05^{\prime} 35^{\prime \prime} \mathrm{W}$ ), and Potholes Reservoir (35 km east of the Columbia River, $46^{\circ} 59^{\prime} 06^{\prime \prime} \mathrm{N}$, $119^{\circ} 18^{\prime} 38^{\prime \prime} \mathrm{W}$.

including copepods and euphausiids (Brett et al. 2009). For example, long-chain $\mathrm{C}_{20}$ and $\mathrm{C}_{22}$ monounsaturated FAs originate from marine copepods, and when present in predator tissues indicate a diet of marine zooplankton or fish that consume marine zooplankton (e.g., Litz et al. 2010). More generally, ratios of FAs may indicate a marine versus freshwater prey base (Smith et al. 1996). For example, primary producers in freshwater systems have lower n-3/n-6 ratios, lower levels of $\mathrm{C}_{20}$ and $\mathrm{C}_{22}$ monounsaturated $\mathrm{FAs}$, and higher levels of $\mathrm{C}_{18}$ polyunsaturated FAs than marine fish (Smith et al. 1996). Analysis of stable isotopes of carbon has also been used successfully to distinguish marine versus freshwater diets (Bearhop et al. 1999); however, FAs may be a more powerful discriminatory tool because as many as 80 FAs can be assessed (Budge et al. 2006).

We used FA analyses to infer dispersal patterns of Caspian Terns among 3 locations in the Columbia River Basin (Fig. 1). East Sand Island, in the marine-freshwater mixing zone of the lower Columbia River estuary, has the largest breeding population of Caspian Terns in the world (Roby et al. 2002). Terns nesting at East Sand Island consume both marine and freshwater prey (Roby et al. 2002). Approximately $350 \mathrm{~km}$ to the east on the Columbia Plateau is the Potholes Reservoir, which is occupied by an inland colony of approximately 300 pairs of Caspian Terns (Bird Research Northwest 2008). Terns nesting in this location forage on freshwater prey from the reservoir and from the Columbia River, approximately $35 \mathrm{~km}$ away (Maranto et al. 2010). Rock Island Dam, located 730 $\mathrm{km}$ from the mouth of the Columbia River, is 1 of 5 midColumbia River dams, where lethal and nonlethal control measures have been used to prevent avian predators from foraging on juvenile salmonids (Wiese et al. 2008).

In 2001, 936 Caspian Terns (half the mid-Columbia River breeding population) were culled from nearby dams, including Rock Island Dam, as part of a management strategy to mitigate predator effects on juvenile salmonids (U.S. Department of Agriculture 2009). Despite this and subsequent lesser annual takes, the breeding population decreased by a maximum of $23 \%$. Thus, we wondered where the population of terns culled at the dams originated. We determined the FA profiles of Caspian Terns to infer the origins of birds lethally taken from Rock Island Dam. Because FA profiles in the adipose tissue of marine birds are an integrated record of diet over weeks, we used a subset of FA biomarkers combined with knowledge of breeding phenology to differentiate between birds from inland breeding colonies and birds from more distant coastal colonies (e.g., East Sand Island).

\section{Methods}

Terns were shot by employees of the U.S. Department of Agriculture Wildlife Services on multiple occasions 
during the 2002 breeding season at Rock Island Dam (March-August); by contract workers of the Washington Department of Fish and Wildlife at the Potholes Reservoir (May-July); and by researchers at East Sand Island (April-July). All collections were part of larger studies of the effects of avian predators on salmonid populations (Roby et al. 2003; Wiese et al. 2008). We divided birds into early and late groups, before or after 15 June, following Wiese et al. (2008), who showed there is a seasonal shift in abundance of juvenile salmonids in the mid-Columbia. We sampled only adult terns, with the exception of 4 hatch-year terns collected from the Potholes Reservoir during the late period.

\section{Signatures of Fatty Acids}

Approximately 30 minutes after death, we placed carcasses on dry ice and transferred them to $-20{ }^{\circ} \mathrm{C}$ freezers. After thawing, adipose tissue was collected from one or more deposits in the body cavity. To date, most studies of seabird foraging ecology in which FA analysis was used sampled adipose tissue, which provides information on diet over 1-2 months (Williams \& Buck 2010). Blood plasma, which can be sampled nonlethally, provides a shorter term diet signature. However, because terns were shot prior to sampling and were not immediately available to us, we could only use adipose tissue for analysis.

We processed tissue samples and analyzed FA concentrations following Herman et al. (2005). In short, we mixed approximately $1 \mathrm{~g}$ of each wet adipose tissue sample with approximately $30 \mathrm{~mL}$ of sodium and magnesium sulfates to remove water, placed the entire mixture into a $33 \mathrm{~mL}$ accelerated-solvent-extraction cell, and then sequentially extracted lipids with $2,25-\mathrm{mL}$ portions of methylene chloride at $100{ }^{\circ} \mathrm{C}$ under 2000 psi. We then partitioned each approximately $50-\mathrm{mL}$ lipid-containing methylene chloride extract into 3 separate aliquots: $46 \%$ for organochlorine analysis, $46 \%$ for gravimetric lipid analysis, and $8 \%$ for FA and lipid-class analyses. We then evaporated each FA aliquot to dryness with an $N_{2}$ evaporator and transesterified the dry lipids to FA methyl esters with $1.5 \mathrm{~mL}$ of $3 \%$ sulfuric acid in dry methanol heated to $80^{\circ} \mathrm{C}$ for 3 hours as the derivitization reagent. The FA methyl esters were then extracted by liquid-liquid partitioning into iso-octane by adding distilled water $(1.5 \mathrm{~mL})$ and iso-octane $(2 \mathrm{~mL})$ to each reaction mixture. We collected the upper iso-octane phase with a Pasteur pipette and then sequentially liquid-liquid extracted each mixture with 2 additional 2-mL-portions of iso-octane. We dried the combined iso-octane extracts (approximately $6 \mathrm{~mL}$ total) over a bed of sodium sulfate. Subsequently we analyzed this material with gas chromatography and mass spectrometry with an Agilent J\&W DB-23 capillary column (60 m length, $250 \mu$ m diameter, $25 \mu \mathrm{m}$ film thickness) coupled to an Agilent 5972 mass selective detector
(Agilent, Santa Clara, California). In most cases, we chose the molecular ion for quantification and monitored a confirmation ion.

We converted all data to weight percent FA methyl ester concentration ([g FA methyl ester/g total FA methyl ester] ${ }^{*} 100$ ). We used shorthand notation of $A: B n X$, where $A$ is the number of carbon atoms, $B$ is the number of double bonds, and $X$ is the position of the first double bond relative to the methyl end of the molecule (Budge et al. 2006). Saturated FAs, monounsaturated FAs, and polyunsaturated FAs have 0,1 , and 2 or more double bonds, respectively.

\section{Statistical Analyses}

We retained only FAs that were dietary in origin (Iverson et al. 2004) and comprised $>0.5 \%$ of the total FA sample across all terns (Supporting Information). These 20 FAs accounted for $86-93 \%$ by mass of the total number of FAs $(n=78)$ over all samples and were subsequently relativized between $0 \%$ and $100 \%$. We assessed patterns of FA composition among terns from different locations and time periods with nonmetric multidimensional scaling (NMDS) and analysis of similarity (ANOSIM).

NMDS is an ordination method that preserves the rankordered distances between sample points in ordination space. It is useful for visualizing differences in FA composition among locations (East Sand Island, Rock Island Dam, and Potholes Reservoir, $n=56$ ) and between time periods (early vs. late for all sites; East Sand Island, $n=12$; Rock Island Dam, $n=23$; Potholes Reservoir, $n=17$, excluding hatch-year terns at Potholes). NMDS is an iterative approach that rearranges samples in ordination space to minimize a measure of disagreement (referred to as stress) between the compositional dissimilarities and the distance between points in the ordination diagram (Kruskal 1964). We used a distance matrix that we based on Euclidean dissimilarity to ordinate the sample sites in 2 dimensions with 100 random starts and tested the significance of the stress value with a Monte Carlo randomization test. Samples with similar FA compositions are closer to each other in multidimensional space, whereas samples with dissimilar FA compositions are farther apart (Kruskal \& Wish 1978). Stress values of $<5 \%, 5-10 \%, 10-20 \%$, and $>20 \%$ indicate ordination with near-zero, minimal, moderate, and high probability of being incorrectly interpreted, respectively (Kruskal 1964).

We used ANOSIM, a nonparametric multivariate procedure analogous to analysis of variance, to test for differences in FA composition among locations and sample time periods. An ANOSIM tests groups defined a priori (i.e., locations, sample time periods) against random groups in ordination space by calculating the average of all rank similarities among samples within groups $\left(r_{w}\right)$ and the average of rank similarities among samples 
between groups $\left(r_{b}\right)$. A test statistic, $R$, is computed. An $R$ value of 1 indicates all samples within groups are more similar to one another than any samples from different groups, a value of zero indicates there is no difference among samples, and a value of -1 indicates all samples within groups are less similar to one another than any samples from different groups. We conducted 999 random permutations to assess the statistical significance of $R$. All analyses were conducted in $R$ version 2.72 (R Development Core Team 2009).

\section{Geographic Origin of Caspian Terns}

Because $\mathrm{C}_{20}$ and $\mathrm{C}_{22}$ monounsaturated FAs originate in marine copepods (Lee et al. 2006), we inferred that terns with higher levels of $\mathrm{C}_{20}$ and $\mathrm{C}_{22}$ monounsaturated FAs had a higher or more recent or both higher and more recent marine diet than those with lower levels (Brett et al. 2009). Therefore, we summed the weight by percent for $\mathrm{C}_{20}$ and $\mathrm{C}_{22}$ monounsaturated FAs (C20:1n15, C20:1n11, C20:1n9, C20:1n7, C20:1n5, C22:1n11, C22:1n9, C22:1n7, C22:1n5) for each tern. We analyzed differences among locations with the Kruskal-Wallis test, those between time periods with Mann-Whitney $U$ tests, and differences in variance between temporal periods with a 2-sample variance test.

To estimate the time since Rock Island terns had emigrated from the coast, and ultimately whether they could have bred successfully at inland colonies, we modeled the rate of loss of FA signature on the basis of Williams et al. (2009), as described below. We applied the model to our data on $\mathrm{C}_{20}$ and $\mathrm{C}_{22}$ monounsaturated FA total weight percent values from East Sand Island and the Potholes Reservoir to anchor marine FA signature maxima and minima, respectively.

Given the literature (Williams et al. 2009 [their Fig. 2]; Käkelä et al. 2009 [their Fig. 2]), we made the simplifying assumption that the functional form of loss of dietary FA signature and the half-life of the signature are the same for all seabirds. The relation between amount of FA signature and time since dietary switch was modeled as

$$
A_{t}=I+\frac{F-I}{\alpha / t+1}+\varepsilon \text { and } \varepsilon \sim N\left(0 ; \sigma^{2}\right),
$$

where $A$ is amount of FA at time $t, t$ is time in days, $I$ is the initial amount of FA, $F$ is the asymptotic value of $\mathrm{FA}, \alpha$ is the parameter that determines the rate at which the amount of FA changes as a function of time, and $\sigma$ is a measure of the extent to which individual tern FA signatures vary about the deterministic relation.

We used data from a feeding study on Tufted Puffin chicks from Williams et al. (2009) to calibrate our model because these were the only published data with which we could calculate a specific loss rate and that included marine-derived monounsaturated FAs. Williams et al. (2009) focused on the rate of gain of a new FA sig- nature given a known time at which the diet changed. We inverted this relation (with data obtained from their Fig. 1b) to examine the rate of loss of the previous signature. Because Williams et al. (2009) measured turnover rates in chicks, which may be faster than adults, we also added a time lag to our calculations of the last day of marine diet (up to a 30\% increase in modeled time since terns departed from the coast [e.g., Table 2]).

We used the $\mathrm{C}_{20}$ and $\mathrm{C}_{22}$ monounsaturated FA signatures from the East Sand Island late birds to estimate $I$ because these terns maximize marine fish in their diets later in the breeding season (Roby et al. 2002) and a higher value is conservative because it reflects a relatively longer time since departure from the coast. We assumed the $\mathrm{C}_{20}$ and $\mathrm{C}_{22}$ monounsaturated FA signatures from the Potholes Reservoir late birds (excluding 3 outliers) estimated $F$ because late-season breeders in the Potholes could not have traveled to the marine environment to forage and thus represented the absolute minima of the marine signature. Four late-season hatch-year terns that could not have consumed marine prey items (Fig. 2) had $\mathrm{C}_{20}$ and $\mathrm{C}_{22}$ monounsaturated FA levels similar to those of adult Potholes terns, which supports this assumption. We considered 3 terns collected in the Potholes Reservoir late sample as outliers because the level of $\mathrm{C}_{20}$ and $\mathrm{C}_{22}$ monounsaturated FAs in their diet was 3 times the level of all other Potholes late-season terns. Because the $\mathrm{C}_{20}$ and $\mathrm{C}_{22}$ monounsaturated FA signature is exclusive to marine zooplankton, we suggest these birds had been foraging at the coast during the peak of chick rearing and thus could not have been breeding at the reservoir.

Our calculations are unlikely to have been confounded by inclusion of hatchery-reared juvenile salmonids in the diet. Although individual samples of hatchery-reared salmonids had a maximum of $7 \% \mathrm{C}_{20}$ and $\mathrm{C}_{22}$ monounsaturated FAs by weight (a single coho [O. kisutch]), average values for all salmonids sampled were generally low (steelhead [O. mykiss], 0.87\% [SE 0.37], $n=2$; Chinook salmon [O. tshawytscha], 1.01\% [0.19], $n=15$; coho salmon, 2.81\% [0.93], $n=7$; sockeye salmon [O. nerka], $1.96 \%$ [0.15], $n=4 ; \mathrm{J}$. Parrish, unpublished data), which is comparable to other nonsalmonid fish captured in the river (1.05\% [0.12], $n=31,10$ species; J. Parrish, unpublished data) and substantially less than marine-forage fish such as Clupeidae (e.g., herring) and Osmeridae (e.g., surf smelt) sampled in nearshore coastal waters of Oregon and Washington (e.g., Litz et al. 2010). Furthermore, Maranto et al. (2010) found that up to $22 \%$ of salmonids delivered to Caspian Tern chicks on the Potholes Reservoir colonies were hatchery-raised rainbow trout (O. mykiss), yet hatch-year birds had extremely low $\mathrm{C}_{20}$ and $\mathrm{C}_{22}$ monounsaturated FA signatures (1.64\% [0.17], $n=4)$.

We estimated the values for $I$ (Caspian Tern data only), $F$ (both Caspian Tern and Tufted Puffin calibration data), $\alpha$ (calibration data only), and $\sigma$ (both data sets) using maximum likelihood. Predictions of the logarithms of 


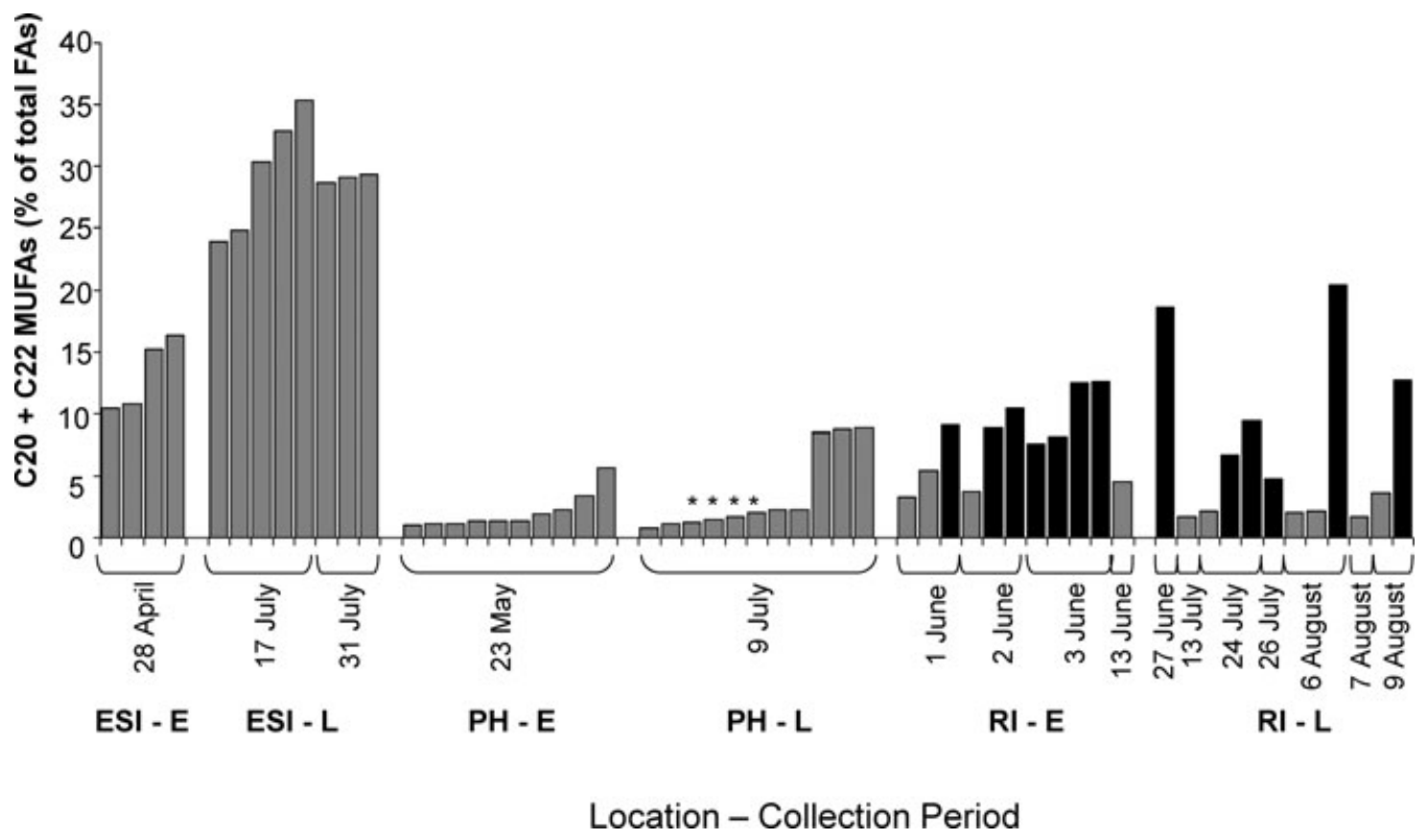

Figure 2. The $C_{20}$ and $C_{22}$ monounsaturated fatty acids (MUFAs) (\% of total fatty acids [FAs]) for individual Caspian Terns collected at East Sand Island (ESI), Rock Island Dam (RI), and Potholes Reservoir (PH) and period of collection ( $E$, early, before 15 June; L, late, after 15 June). Individuals within each location-time period category are displayed on the figure by collection date and in ascending order by FA ratio ( ${ }^{*}, 4$ hatch-year terns collected at the Potholes Reservoir; black, Rock Island Dam terns that could not have bred at inland tern colonies given model results and known breeding phenology).

$t$ were obtained by sampling values for $\varepsilon$ from the distribution for the residual errors along with values for the parameters of Eq. 1 from their sampling distributions and then solving for $t$. This process allowed for both parameter uncertainty and the effect of measurement error about the fitted curve.

\section{Results}

\section{Differences in FA Signatures}

There were clear differences in Caspian Tern FA signatures as a function of location (Fig. 3a). The NMDS analysis for the location comparison produced a significant, low-stress value (Table 1), which indicated high confidence in the distances between terns within the ordination plot. East Sand Island terns were differentiated by long-chain monounsaturated FAs, including C20:1n11, C20:1n9, C22:1n11, and C22:1n9 (Fig. 3b \& Supporting Information) and a relatively high n-3:n-6 ratio (Supporting Information). Potholes terns were characterized by high levels of polyunsaturated FAs, particularly C18:3n3, C20:4n6, and C22:5n3; shorter chain monounsaturated FAs, such as C18:1n 7 and C16:1n 7, and a low n-3:n-6 ratio (Fig. 3b \& Supporting Information). Fatty acid signatures from Rock Island Dam terns were intermediate, overlap- ping primarily with the Potholes' breeding population in ordination space (i.e., high C18:3n3 and C20:4n6), but these signatures were also similar to signatures of terns from East Sand Island (i.e., presence of $\mathrm{C}_{20}$ and $\mathrm{C}_{22}$ monounsaturated FAs) and expressed high levels of C18:1n9 and C18:2n6 (Fig. 3b, Supporting Information).

Results of ANOSIM analyses by location supported the differences in group positions in NMDS ordination space (Table 1). Fatty acid composition of Rock Island Dam terns was more similar to Potholes terns (ANOSIM $R=0.24, p=0.001)$ than to East Sand Island terns $(r=0.60, p<0.001$; Table 1$)$.

Within each location, NMDS ordinations comparing early versus late terns produced significant, low stress values (Fig. 4 \& Table 1). Early terns from East Sand Island had high levels of $n-3$ and $n-6$ polyunsaturated FAs, whereas late terns had high levels of $\mathrm{C}_{20}$ and $\mathrm{C}_{22}$ monounsaturated FAs (Fig. 4a). Fatty acids of Rock Island Dam terns were dominated by polyunsaturated FAs during early and late periods, except for 3 late-season terns with signatures high in $\mathrm{C}_{20}$ and $\mathrm{C}_{22}$ monounsaturated FAs (Fig. 4b). Early and late tern FA signatures at the Potholes overlapped more in distribution than early and late tern signatures at both Rock Island Dam and East Sand Island, and $\mathrm{C}_{20}$ and $\mathrm{C}_{22}$ monounsaturated FAs were absent from most Potholes samples (Fig. 4c \& Table 1). 

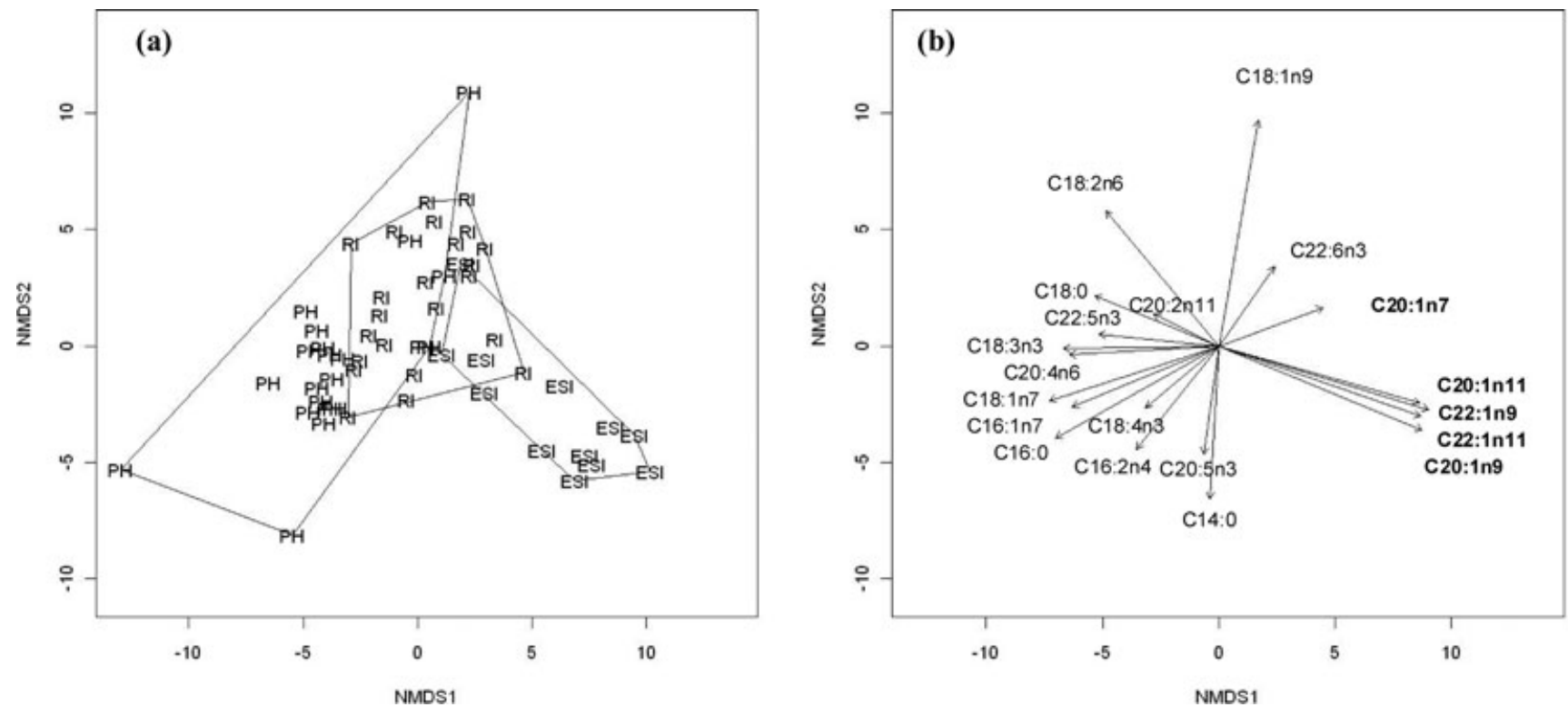

Figure 3. (a) Nonmetric multidimensional scaling (NMDS) ordination plot (2 dimensional) of diet differences among Caspian Terns (as expressed by relative percent weight of 20 prevalent dietary fatty acids) at 3 sites in the Columbia River Basin: East Sand Island (ESI), Rock Island Dam (RI), and the Potholes Reservoir (PH). Each abbreviation denotes a single tern and polygons encompass $100 \%$ of the site sample (i.e., convex hull). (b) Correlations between the fatty acids and NMDS axes expressed by vectors in ordination space $\left(C_{20}\right.$ and $C_{22}$ monounsaturated FAs are in bold).

\section{Origin of Caspian Terns Foraging on Mid-Columbia Dams}

Terns from all locations had significantly different mean percentages of $\mathrm{C}_{20}$ and $\mathrm{C}_{22}$ monounsaturated FAs (Kruskal-Wallis: $H=34.4, p<0.001$, Fig. 2). East Sand Island terns had the highest level of $\mathrm{C}_{20}$ and $\mathrm{C}_{22}$ monounsaturated FAs (mean $[\mathrm{SE}]=23.9 \%[1.5]$ ) and a significant increase in mean percentage between the early (13.2 [1.7]) and late $(29.3[1.2])$ periods (Mann-Whitney $U$ test: $Z=-2.72, p<0.01)$, indicated an increase in proportion of marine food items (Roby et al. 2002). By contrast, terns nesting at the Potholes Reservoir had consistently and significantly lower mean $\mathrm{C}_{20}$ and $\mathrm{C}_{22}$ monounsaturated FA values than terns from East Sand Island. There was no difference in mean percentages of $\mathrm{C}_{20}$ and $\mathrm{C}_{22}$ monounsaturated FAs between the early and late time periods (Mann-Whitney $U$ test: $Z=-0.915, p=0.359$ ) for Potholes terns. Values of $\mathrm{C}_{20}$ and $\mathrm{C}_{22}$ monounsaturated FAs in Rock Island Dam samples were intermediate (Fig. 2). Although there was no mean difference between time periods (Mann-Whitney $U$ test: $Z=1.046, p=0.295$ ), variance was significantly greater during the late period (2-sample variance; $F_{11,10,0.05(2)}=4.19, p<0.05$ ). By contrast, variance of $\mathrm{C}_{20}$ and $\mathrm{C}_{22}$ monounsaturated FAs between the early and late periods on East Sand Island (2-sample variance test; $F_{7,3,0.05(2)}=1.56, p=0.77$ ) and the Potholes Reservoir did not differ significantly

Table 1. Nonmetric multidimensional scaling and analysis of similarity results for comparisons of Caspian Tern fatty acid signatures among locations (East Sand Island, Rock Island Dam, and Potholes Reservoir) and temporal periods (early and late ${ }^{a}$ ).

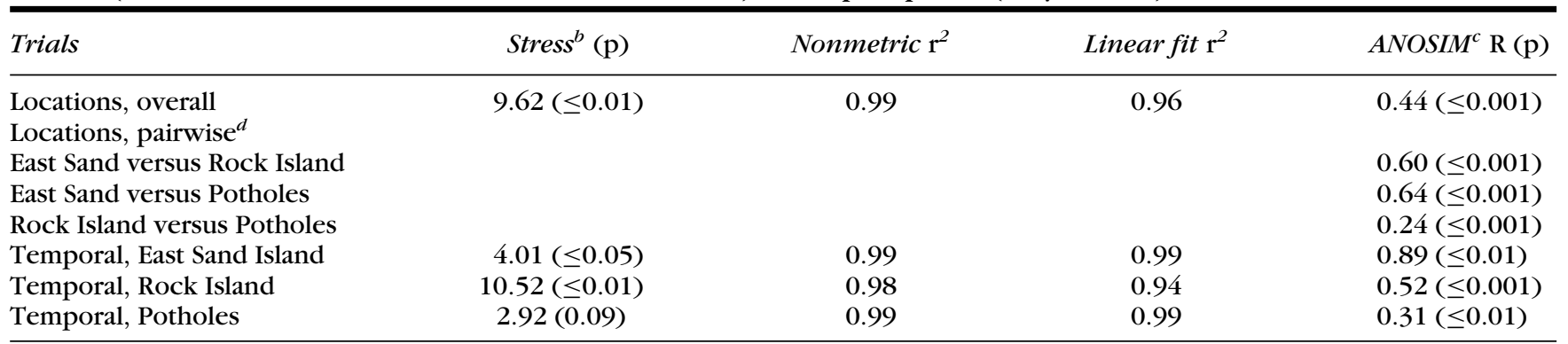

${ }^{a}$ Terns were grouped according to whether they were collected before 15 June (early) or after 15 June (late).

${ }^{b}$ Stress values of $<5 \%, 5-10 \%, 10-20 \%$, and $>20 \%$ indicate ordination with near-zero, minimal, moderate, and bigh probability of being incorrectly interpreted, respectively (Kruskal 1964).

${ }^{c}$ Analysis of similarity.

${ }^{d}$ The ANOSIM Pairwise comparisons were only performed for the spatial analysis because there were more than 2 groups. 

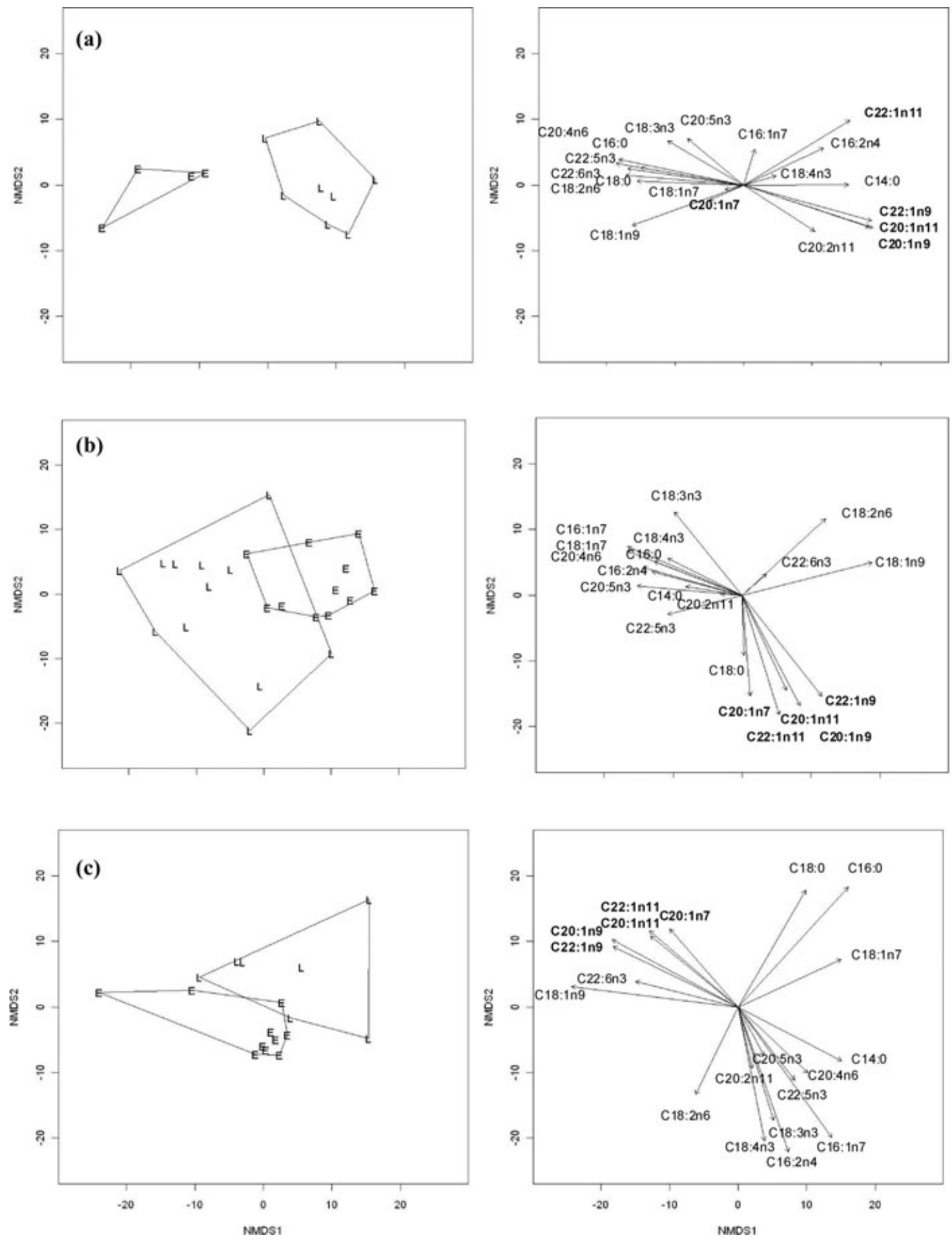

Figure 4. Two-dimensional nonmetric multidimensional scaling ordination plot illustrating fatty acid composition of Caspian Terns from (a) East Sand Island, (b) Rock Island Dam, and (c) Potholes Reservoir as a function of collection period (E, early, before 15 June; L, late, after 15 June). All other symbols are as in Fig. 3.

(when outlier terns were excluded; $F_{8,7,0.05(2)}=1.82$, $p=0.44)$.

Of 23 terns collected at Rock Island Dam throughout the breeding season, 18 had $\mathrm{C}_{20}$ and $\mathrm{C}_{22}$ monounsaturated FA signatures above the maximum value for Pot- holes late birds (excluding outliers), including all early season birds and over half the late-season birds (Fig. 2). Results of the FA signature-loss model suggested many of these birds were recent arrivals to the mid-Columbia River system, 12 arriving within a month of modeled time 
Table 2. Estimates of the time (days) since Caspian Terns culled at Rock Island Dam departed from the coast.

\begin{tabular}{|c|c|c|c|}
\hline \multicolumn{2}{|c|}{ Rock Island early } & \multicolumn{2}{|c|}{ Rock Island late } \\
\hline (days) & $C V$ & (days) & $C V$ \\
\hline 93.8 & 1.66 & 3.9 & 0.39 \\
\hline 38.4 & 0.79 & 1919.3 & 30.72 \\
\hline 16.4 & 0.47 & 280.7 & 4.63 \\
\hline 70.9 & 1.30 & 27.0 & 0.62 \\
\hline 17.4 & 0.48 & 15.6 & 0.46 \\
\hline 13.1 & 0.43 & 46.8 & 0.92 \\
\hline 22.1 & 0.55 & 428.7 & 6.99 \\
\hline 19.5 & 0.51 & 339.5 & 5.57 \\
\hline 9.5 & 0.39 & 2.9 & 0.43 \\
\hline 9.3 & 0.39 & 1919.3 & 30.72 \\
\hline \multirow{2}{*}{50.3} & 0.98 & 74.6 & 1.36 \\
\hline & & 9.1 & 0.39 \\
\hline
\end{tabular}

* The order of terns listed in this table corresponds to the order of terns displayed in Fig. 2. Terns grouped according to whether they were collected before (early) or after (late) 15 June.

since dietary change (Table 2). Calculation of time since departure from the marine environment was not possible for Rock Island Dam birds with $\mathrm{C}_{20}$ and $\mathrm{C}_{22}$ monounsaturated FA values approaching those displayed by Potholes' birds because the FA signature is essentially independent of day for over 60 days once account is taken of both parameter and measurement error.

To have bred successfully at the Potholes, adults must have arrived at least 1 week prior to the median egg-laying date of the colony or by 12 May. Subtracting our modeled time since departure (Table 2) from the collection date suggested that 9 terns could have bred at the Potholes (modeled arrival dates of 24 April or earlier) and an additional bird may have been successful (modeled arrival date of 12 May). When we applied a time lag to these results an additional 1 (20\% increase in time since departure) to 4 birds ( $30 \%$ increase) could have bred successfully (modeled arrival dates between 3 and 11 May). Applying this same logic to breeding phenology at East Sand Island (with earliest fledging date as the threshold) suggested that between 4 and 5 terns collected from Rock Island Dam could have bred successfully on the coast.

\section{Discussion}

\section{Spatial and Temporal Differences in FA Signatures}

Fatty acid signatures were clearly differentiated among the 3 tern populations we sampled in the Columbia River Basin. Marine FA biomarkers decreased (i.e., $\mathrm{C}_{20}$ and $\mathrm{C}_{22}$ monounsaturated FAs) and freshwater FA biomarkers increased (i.e., higher $\mathrm{C}_{18}$ polyunsaturated $\mathrm{FAs}$ and decreasing $n-3: n-6$ ratio) from the coastal East Sand Island population to the inland group at the Potholes. Because $\mathrm{C}_{20}$ and $\mathrm{C}_{22}$ monounsaturated FAs originate in marine copepods
(Lee et al. 2006), high levels of these FAs in terns from East Sand Island suggest they foraged on zooplanktivorous fish from the nearshore marine environment. Roby et al. (2002) found that apart from juvenile salmonids, East Sand Island terns forage primarily on marine prey, principally Pacific herring (Clupea pallasi). For herring collected along the coast of Oregon and Washington at sites adjacent to the Columbia River, total monounsaturated FAs ranged between $21 \%$ and $42 \%$ of all FAs across years $(2005,2006)$ and time of year, indicating that although the diets of these fish may fluctuate greatly, consistently high values of $\mathrm{C}_{20}$ and $\mathrm{C}_{22}$ monounsaturated FAs appear to be specific to species and perhaps region (Litz et al. 2010).

By contrast, Potholes terns had relatively high amounts of $\mathrm{C}_{18}$ polyunsaturated $\mathrm{FAs}$ and $\mathrm{n}-3: \mathrm{n}-6$ ratios between 0.5-3.8, both indications of freshwater foraging (Supporting Information) (Smith et al. 1996). Temporal differences were also apparent. Early terns had high levels of $\mathrm{C}_{18}, \mathrm{C}_{20}$ and $\mathrm{C}_{22}$ polyunsaturated $\mathrm{FAs}$, whereas late terns had high levels of saturated FAs and C18:1n7. Although we had minimal information on what may have caused this dietary shift, 3 possibilities exist: Potholes terns may forage in different habitats throughout the season (C.J.M, unpublished data), the prey base at the Potholes Reservoir may shift, or both. Seasonal shifts in freshwater zooplankton community structure may translate into demonstrably different FA signatures in fish and upper-trophic-level consumers such as birds (Brett et al. 2009).

\section{Origin and Management of Rock Island Terns}

Lethal control of animal populations is not uncommon (Sabo 2005). Knowledge of dispersal dynamics can be important when attempting to assess whether local or regional abundance of the culled species is reduced, particularly in cases where predators are drawn to artificially concentrated prey. At mid-Columbia River dams, including Rock Island, lethal control programs were established in the late 1990s to reduce the effects of avian predators on juvenile salmonids. In 1998, 84 Caspian Terns were shot at mid-Columbia River dams. By 2004, total take reached 1728 terns (U.S. Department of Agriculture 2009), or just over $100 \%$ of the average mid-Columbia River breeding population during the same time window (1718 terns) (Bird Research Northwest 2008). Thus, terns must be immigrating from elsewhere.

Our results suggest that $39-56 \%$ of the terns taken while foraging at Rock Island Dam could not have bred successfully within the mid-Columbia plateau and an additional $4-22 \%$ were unlikely to have been successful. Several factors could alter these values. If chicks have a substantially faster turnover rate than adult birds, even our 30\% time lag may not have captured this difference, and differences in FA turnover between adults and chicks 
are unknown (Williams \& Buck 2010). Conversely, it is possible that the starting concentration of $\mathrm{C}_{20}$ and $\mathrm{C}_{22}$ monounsaturated FAs was lower than we modeled for early-season birds taken at Rock Island; for instance, it might have been closer to concentrations in the earlyseason terns at East Sand Island (Fig. 2). Decreasing the starting concentration would effectively shorten the calculated time since departure from the coast and decrease the estimated number of terns that could have bred successfully at the inland colony. It is likely that a majority of the terns taken while foraging at the mid-Columbia were not nesting at the closest colony and most likely came from coastal locations. Because monitoring dispersal is difficult and expensive (Peery et al. 2006), FA biomarker analyses combined with simple modeling of the timing of dietary turnover provides a novel, and potentially effective, way to study dispersal when source populations of animals differ demonstrably in their prey base.

Results of several studies show that local, lethal-control programs may be ineffective if the source of predator attraction remains unchanged. For example, local immigration rates of culpeo foxes (Pseudalopex culpaeus) in Argentina increased after hunting temporarily decreased local abundance (Novaro et al. 2005). Similarly, Robinson et al. (2008) found that cougars immigrated into areas where the species was hunted due to conflicts with humans. Because the largest Caspian Tern breeding colony in the world is located at East Sand Island (Roby et al. 2003), a steady source of dispersers from the coast will likely be maintained despite aggressive lethal control in the mid-Columbia.

Our results suggest terns foraging along the midColumbia River dispersed primarily from marine sites (Fig. 2). Thus, although lethal control at the dams may not negatively affect local tern populations, proposals to stem the movement of coastal tern colonies to off-river inland sites such as the Potholes Reservoir (U.S. Fish and Wildlife Service 2005) or remove these inland colonies altogether are unlikely to reduce predation on salmonids because these local birds are not the ones foraging at the dams. We believe understanding the origin of predators at sites that concentrate prey of high management value is an important step when establishing local, lethalcontrol programs designed to address that very predator attraction.

\section{Acknowledgments}

Work was performed under University of Washington Institutional Animal Care Use Committee protocol (2994-08) and U.S. Fish and Wildlife Service collection permits (MB0-086121 and MB 827457-0). Funding was provided by a contract from Chelan County Public Utility District to J.K.P. We thank E. Donelan, M. Krahn, D.
Brown, C. Sloan, R. Boyer, and R. Pearce for help with project implementation.

\section{Supporting Information}

Fatty acid composition of adipose tissue collected from terns at East Sand Island, Rock Island Dam, and the Potholes Reservoir (Appendix S1) are available online. The authors are solely responsible for the content and functionality of these materials. Queries (other than the absence of the material) should be directed to the corresponding author.

\section{Literature Cited}

Barrett, R. T., C. J. Camphuysen, T. Anker-Nilssen, J. W. Chardine, R. W. Furness, S. Garthe, O. Huppop, M. F. Leopold, W. A. Montevecchi, and R. R. Veit. 2007. Diet studies of seabirds: a review and recommendations. ICES Journal of Marine Science 64:1675-1691.

Bearhop, S., D. R. Thompson, S. Waldron, I. C. Russell, G. Alexander, and R. W. Furness. 1999. Stable isotopes indicate the extent of freshwater feeding by cormorants Phalacrocorax carbo shot at inland fisheries in England. Journal of Applied Ecology 36:75-84.

Bird Research Northwest. 2008. Avian predation report -Columbia Basin, 2008 Draft Season summary. Real Time Research, Bend, Oregon. Available from http://www.birdresearchnw.org/ CEDocuments/Downloads_GetFile.aspx?id=349567\&fd=0. (accessed March 2009).

Brett, M. T., D. C. Muller-Navarra, and J. Persson. 2009. Crustacean zooplankton fatty acid composition. Pages 115-146 in M. T. Arts, M. T. Brett, and M. J. Kainz, editors. Lipids in aquatic ecosystems. Springer Publishing, New York.

Budge, S. M., S. J. Iverson, and H. N. Koopman. 2006. Studying trophic ecology in marine ecosystems using fatty acids: a primer on analysis and interpretation. Marine Mammal Science 22:759-801.

Dalsgaard, J., M. St John, G. Kattner, D. Muller-Navarra, and W. Hagen. 2003. Fatty acid trophic markers in the pelagic marine environment. Advances in Marine Biology 46:225-340.

Goodrich, J. M., and S. W. Buskirk. 1995. Control of abundant native vertebrates for conservation of endangered species. Conservation Biology 9:1357-1364.

Hanski, I., and D. Simberloff. 1997. The metapopulation approach, its history, conceptual domain, and application to conservation. Pages 5-26 in I. A. Hanski and M. E. Gilpin, editors. Metapopulation biology: ecology, genetics, and evolution. Academic Press, San Diego, California.

Herman, D. P., D. G. Burrows, P. R. Wade, J. W. Durban, C. O. Matkin, R. G. Le Duc, L. G. Barrett-Lennard, and M. M. Krahn. 2005. Feeding ecology of eastern North Pacific killer whales Orcinus orca from fatty acid, stable isotope, and organochlorine analyses of blubber biopsies. Marine Ecology Progress Series 302:275-291.

Hobson, K. A., G. Gilchrist, and K. Falk. 2002. Isotopic investigations of seabirds of the north water polynya; contrasting trophic relationships between eastern and western sectors. Condor 10:1-11.

Iverson, S. J., C. Field, W. D. Bowen, and W. Blanchard. 2004. Quantitative fatty acid signature analysis: a new method of estimating predator diets. Ecological Monographs 74:211- 235.

Käkelä, R., R. W. Furness, S. Kahle, P. H. Becker, and A. Käkelä. 2009. Fatty acid signatures in seabird plasma are a complex function of diet composition: a captive feeding trial with herring gulls. Functional Ecology 23:141-149.

Kruskal, J. B. 1964. Nonmetric multidimensional scaling: a numerical method. Psychometrika 29:115-129. 
Kruskal, J. B., and M. Wish. 1978. Multidimensional scaling. Sage Publications, Beverly Hills, California.

Lee, R. F., W. Hagen, and G. Kattner. 2006. Lipid storage in marine zooplankton. Marine Ecology Progress Series 307:273-306.

Litz, M. N. C., R. D. Brodeur, R. K. Emmett, S. S. Heppell, R. S. Rasmussen, L. O'Higgins, and M. S. Morris. 2010. Effects of variable oceanographic conditions on forage fish lipid content and fatty acid composition in the northern California Current. Marine Ecology Progress Series 405:71-85.

Maranto, C. J., T. P. Good, F. K. Wiese, and J. K. Parrish 2010. Impact of the Potholes Reservoir Caspian Tern breeding colony on out-migrating juvenile salmonids in the mid-Columbia River. Transactions of the American Fisheries Society 139:362381.

McClure, M. M., E. E. Holmes, B. L. Sanderson, and C. E. Jordan. 2003. A large-scale, multispecies status assessment: anadromous salmonids in the Columbia River Basin. Ecological Applications 13:964-989.

National Marine Fisheries Service. 2002. Final environmental impact statement for anadromous fish agreements and habitat conservation plans for the Wells, Rocky Reach and Rock Island hydroelectric projects. National Marine Fisheries Service, Northwest Region, Seattle.

Novaro, A. J., M. C. Funes, and R. S. Walker. 2005. An empirical test of source-sink dynamics induced by hunting. Journal of Applied Ecology 42:910-920.

Peery, M. Z., B. H. Becker, and S. R. Beissinger. 2006. Combining demographic and count-based approaches to identify source-sink dynamics of a threatened seabird. Ecological Applications 16:1516-1528.

R Development Core Team. 2009. R: a language and environment for statistical computing. R Foundation for Statistical Computing, Vienna.

Robinson, H. S., R. B. Wielgus, H. S. Cooley, and S. W. Cooley. 2008. Sink populations in carnivore management: cougar demography and immigration in a hunted population. Ecological Applications 18:1028-1037.

Roby, D. D., K. Collis, D. E. Lyons, D. P. Craig, J. Y. Adkins, A. M. Myers, and R. M. Suryan. 2002. Effects of colony relocation on diet and productivity of Caspian Terns. The Journal of Wildlife Management 66:662-673.

Roby, D. D., D. E. Lyons, D. P. Craig, K. Collis, and G. H. Visser. 2003. Quantifying the effect of predators on endangered species using a bioenergetics approach: Caspian Terns and juvenile salmonids in the Columbia River estuary. Canadian Journal of Zoology 81:250-265.

Sabo, J. L. 2005. Stochasticity, predator-prey dynamics, and trigger harvest of nonnative predators. Ecology 86:2329-2343.

Smith, R. J., K. A. Hobson, H. N. Koopman, and D. M. Lavigne. 1996 Distinguishing between populations of fresh-and salt-water harbour seals (Phoca vitulina) using stable-isotope ratios and fatty acid profiles. Canadian Journal of Fisheries and Aquatic Sciences 53:272-279.

Thiemann, G. W., S. J. Iverson, and I. Stirling. 2008. Variation in blubber fatty acid composition among marine mammals in the Canadian Arctic. Marine Mammal Science 24:91-111.

U.S. Department of Agriculture (USDA). 2009. Program data reports USDA, Washington, D.C. Available from http://www.aphis.usda. gov/wildlife_damage/prog_data/2009_prog_data/data_index_2009. shtml (accessed March 2009).

U.S. Fish and Wildlife Service (FWS). 2005. Caspian Tern management to reduce predation of juvenile salmonids in the Columbia River estuary. Final environmental impact statement. FWS, Portland, Oregon.

Wiese, F., J. Parrish, C. Thompson, and C. Maranto. 2008. Ecosystembased management of predator - prey relationships: piscivorous birds and salmonids. Ecological Applications 18:681-700.

Williams, C. T., S. J. Iverson, and C. L. Buck. 2009. The effects of diet and caloric restriction on adipose tissue fatty acid signatures of tufted puffin (Fratercula cirrbata) nestlings. Journal of Comparative Physiology B 179 711-720.

Williams, C. T., and C. L. Buck. 2010. Using fatty acids as dietary tracers in seabird trophic ecology: theory, application and limitations. Journal of Ornithology 151:531-543.

Wires, L. R., and F. J. Cuthbert. 2000. Trends in Caspian Tern numbers and distribution in North America: a review. Waterbirds 23:388-404.

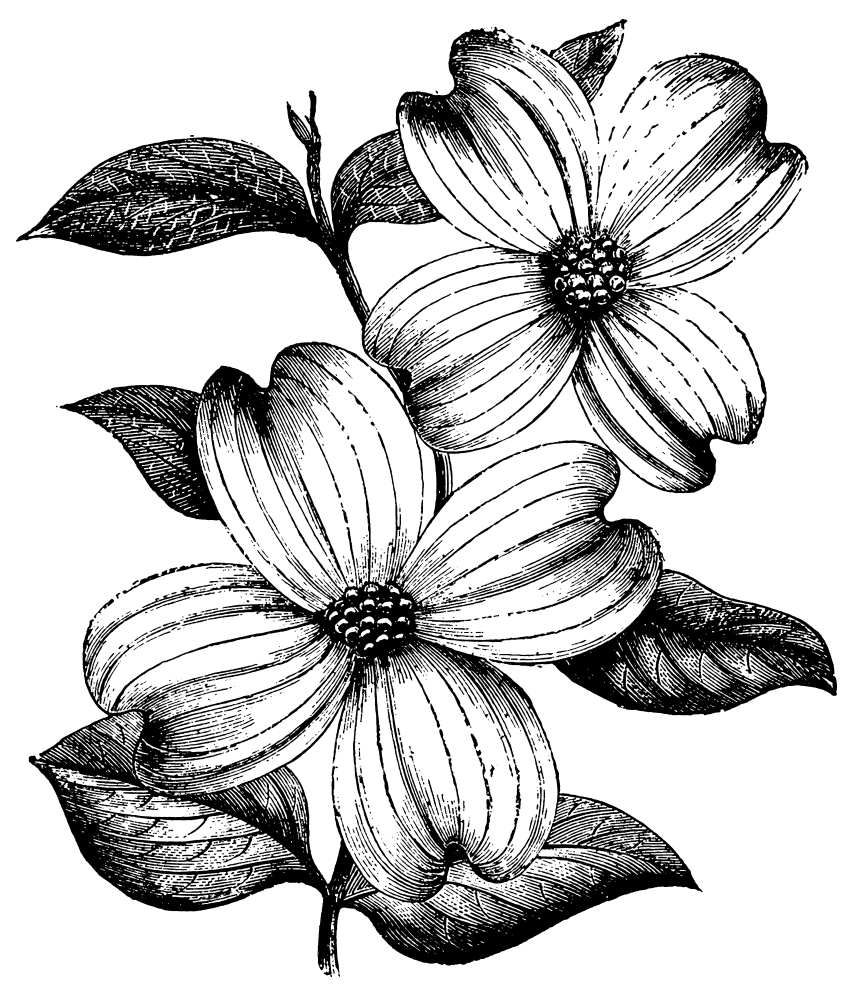

